\title{
Social Policy and Human Rights: Re-thinking the Engagement
}

\author{
Hartley Dean \\ Department of Social Policy, London School of Economics and Political Science \\ E-mail: h.dean@lse.ac.uk
}

It is argued that the encompassing concept of welfare rights that is contained within the Social Policy literature - and which has developed from TH Marshall's distinction between civil and political rights on the one hand and social or welfare rights on the other provides a clearer and more explicit basis for an international call for the progressive development of social policies than, for example, the human rights approach to poverty reduction currently espoused by the UNDP and OHCHR. Social rights continue to be a relatively marginalised or qualified element of the human rights agenda and may be more effectively harnessed by way of a welfare rights approach based on a politics of needs interpretation.

This article is concerned with the relationship between academic Social Policy and the human rights agenda. It will examine notions of rights from the perspective of Social Policy as an academic subject ${ }^{1}$ before presenting a three pronged critique: it will critically examine recent attempts to frame a 'human rights approach' to global poverty reduction; it will contend that welfare rights have been and continue within contemporary debates to be marginalised; it will argue for the incorporation of an alternative conception of welfare rights as a component of the human rights agenda.

\section{Welfare rights and human rights}

As an inter- and multidisciplinary academic subject Social Policy has championed the classic sociological formulation espoused by TH Marshall, who identified three kinds of citizenship rights: civil or legal rights, political or democratic rights and social or welfare rights (Marshall, 1950). The capitalist welfare state gave expression to the latter. Marshall's contention was that in liberal democracies the struggles of past centuries had delivered first the rule of law and then the universal franchise. However, the crowning achievement of the twentieth century - brought to fruition following the end of the Second World War had been the consolidation of more or less systematic forms of social policy across the capitalist world, providing certain rights to social security, healthcare, education, housing, social protection and, for example, legal aid for the poor. Democratic welfare capitalism, Marshall supposed, would secure equality of status for the individual citizens of nation states.

It is citizenship rights that have in practice provided the foundations upon which modern global conceptions of human rights have been constructed (e.g. Clarke, 1996). The human rights instruments of the modern era - including and particularly the 1948 Universal Declaration of Human Rights (UDHR) and its subsequent international 
covenants - generally assert the indivisibility of all human rights, yet they incorporate the same distinction that Marshall drew between a 'first generation' of civil and political rights that had been defined though past struggles and a 'second generation' of rights identified in the twentieth century. The UDHR characterises this second generation of rights as economic, social and cultural. Such rights relate to the means by which human beings obtain their livelihood and the ways in which they are able to participate in human society. This is by implication the very stuff of Social Policy. More explicitly, the United Nations 1993 Vienna Declaration has asserted that 'extreme poverty and social exclusion constitute a violation of human dignity' (UN General Assembly, 1993: para. 25). Insofar as the amelioration of poverty and social exclusion is a fundamental social policy objective, the human rights agenda ostensibly embraces the concerns of Social Policy.

It is argued, nonetheless, that moral demands for economic, social and cultural justice are incapable of universal achievement and should not be regarded as human rights at all (Cranston, 1973); that the language of human rights is not necessarily appropriate to the pursuit of social justice through public policy making (McLachlan, 2005). Social Policy has engaged not so much with the idea of human rights as with Marshall's more specific concept of social citizenship, and with an encompassing notion of welfare rights: a notion that loosely captures the economic, social and economic components of human rights in terms of entitlements created through social legislation and the practices associated with promoting such entitlements (Dean, 2002). The welfare rights concept has therefore been essentially pragmatic. It takes into account that social rights of citizenship are shaped through the exercise of political rights or processes; and that civil or legal rights are required for the purposes of their enforcement.

The form and substance of welfare rights have always been contestable. Different 'welfare regimes' (Esping-Andersen, 1990) function with different notions of rights. Within the liberal English-speaking tradition there has been a certain tendency to look upon welfare rights in terms of safety nets for the relief of poverty or national minima for the prevention of poverty. In contrast, corporatist continental-European welfare states have tended to see welfare rights as compensatory rights for their nations' workers, whereas Nordic social-democratic welfare states have been inclined to regard welfare rather more in terms of universal rights for all citizens. Fundamentally, however, welfare rights are rights that have in various ways been bestowed or demanded under capitalism.

In contrast, second generation human rights have been conceptually more abstract and practically more elusive. The form in which they were encapsulated in the UDHR owed much to the Cold War tensions of that era (e.g. Hunt, 1996). They represented an uncomfortable compromise between, on the one hand, a liberal legacy summed up in Franklin Roosevelt's celebrated aphorism that 'a necessitous man is not a free man' (see Eide, 2001) and, on the other, attempts by the Soviet communist bloc to inflect the agenda away from civil and political freedoms in favour of its own interpretation of human rights, based on state organised economic and social guarantees (e.g. Wronka, 1992). Despite rhetorical assertions as to the indivisibility and interdependence of all human rights, these tensions as to their substance - and as to the manner of their implementation and enforcement - led to the development of separate international covenants: one for civil and political rights, the other for economic, social and cultural rights. Later, with the collapse of Soviet communism, human rights discourse became - for a time at least - less of a rhetorical propaganda medium (UNDP, 2000: 3). 
In the meantime, in response to the demands of the global south, the UN through the 1986 Declaration of the Right to Development purported to institute a 'third generation' of human rights. The Declaration was intended, in the words of the Senegalese delegate, to express for the poorest people of the world 'the right to live better'. It sought to establish the principle that all human beings should be enabled to participate in a process of social, economic and political development (Rosas, 2001: 122). This new generation of rights incorporated demands for peace, a healthy environment and self-determination. It implied not only individual rights, but collective, group and solidarity rights. In the process, however, it did not so much add to the canon of rights already set out in the 1966 International Covenant on Economic, Social and Cultural Rights (ICESCR) as bring an element of ambiguity to the question of whether 'the right to live better' was a right to be demanded by citizens against individual nation states or a right of poor nations to international co-operation and assistance. Paradoxically, perhaps, this has served further to marginalise the idea that social or welfare rights may be regarded as a global species of human rights that could or should in themselves be inalienable and unconditional. Aspirations based, for example, on group-rights to self-determination and/or cultural freedom (Kymlicka, 1995; Perez-Bustillo, 2001) seek to enlarge our understanding of civil and political rights, not economic and social rights.

Within Social Policy there have been concerns expressed as to whether a rights-based approach to welfare can be sustained in the face of economic globalisation (Mishra, 1999) and a realisation that the assumptions underpinning the idea of welfare rights do not readily translate to the poorest nations of the world (Gough et al., 2004). Nonetheless, it has been argued that it is now feasible at the international level to entertain the possibility of global approaches to social policy issues (Deacon, 1997). The specific object of this article is to retrieve a conception of welfare rights and situate it more firmly in relation to the theories and discourses of human rights.

\section{A human rights approach to poverty reduction?}

The intuitively attractive idea of a human rights approach to poverty reduction took hold with the publication of the Human Development Report 2000 (UNDP, 2000). Chapter 1 of that report was contributed by the Nobel Prize winning economist, Amartya Sen, who took the opportunity to explore the connection between human rights and human development. Sen's argument was that rights nourish our freedom, while development nourishes our capabilities (see also Sen, 1999). By capabilities, Sen was referring not to the things that people may be able to do (their 'functionings'), but to their capacity to choose and to live a life they value. Human rights may be expressed in terms of goals for human functioning, but human development depends axiomatically on freedom to achieve those chosen goals. For Sen, poverty is to be understood as capability deprivation. He draws upon Kant's distinction between perfect and imperfect duties to make the point that just because the rights demanded by or on behalf of the poor are neglected or repudiated by those with the power to honour them, this does not mean that such rights cannot be inalienable. Sen's influence on the United Nations Development Programme and on international financial institutions such as the World Bank has been notable, and yet it may be argued (Dean, 2002, 2004) that the international establishment has not properly embraced his central premise. 
The prevailing establishment discourse - which shines through in later chapters of the Human Development Report 2000 - assumes that human development requires economic growth; rights require liberal democracy; and both require a pluralistic and largely de-politicised public realm in which non-governmental organisations and civil society groups can play a role as much as the state. It is claimed that economic, social and cultural rights are as important as civil and political rights (UNDP, 2000: 9). And yet, it would seem, the rights that matter most are rights to free trade. Fostering human development, therefore, is a matter of creating incentive structures, furnishing appropriate regulation and facilitating participation. Poor countries, it is supposed, should avail themselves of the opportunities that capitalist globalisation can provide. The later chapters of the Human Development Report 2000 slip into the discourse of new public managerialism (Clarke and Newman, 1997; Clarke, 2004; Braathen, 2005): rights to social development are to be achieved through technocratic processes, requiring such managerial techniques as self-assessment, benchmarking and culture change.

In the course of the Human Development Report 2000 the term 'human capital' is insinuated as if it were a synonym for Sen's notion of 'human capabilities'. Sen, himself has remarked upon the limitations of the term human capital on the grounds that 'human beings are not merely means of production, but also the end of the exercise' (1999: 296). Concepts such as human capital and social capital (e.g. Putnam, 2000) have become common currency within the dominant discourse. Though they may have an application within critical sociological analysis (e.g. Bordieu, 1997), as metaphors in policy discourse they take on distinctly reductive economistic meanings: individuals are constituted as actual or potential economic actors; societies are constituted as more or less functional or dysfunctional networks of actors. It is an approach that continues to reflect essential elements of the economic and political orthodoxy once dubbed the 'Washington Consensus' (Williamson, 1990). The recipe for tackling poverty still favours the liberalisation of trade and financial markets, the privatisation and deregulation of economic production, flexible labour markets, low public spending and taxation, and selective social 'safety nets' (generally, that is, means-tested and/or conditional forms of social assistance for the poorest). The neo-liberal legacy of that consensus is an enduring hostility to 'big' government and scepticism towards welfare rights.

The Human Development Report 2003 (UNDP, 2003), announced the UN's Millennium Development Goals, by which it aims to eradicate poverty and promote human development in the course of the twenty-fist century. 'Daunting' though these goals are held to be (ibid: 13), the specific aim of halving the incidence of extreme poverty and hunger by 2015 very clearly does not announce that freedom from extreme poverty or hunger is an inalienable human right. Implicit here is the principle of 'progressive realisation', provided in Article 2 of the ICESCR, elaborated by the Limburg Principles promulgated on behalf the International Commission of Jurists in 1986 (see Hunt, 1996: Appendix 5) and consolidated in 1990 by a General Comment of the UN Committee on Economic, Social and Cultural Rights (see Eide, 2001: 22). The later formulations owe something to the 'typology of duties' defined by Shue (1980), who had argued that state parties to human rights instruments were obliged in the first instance only to respect rights by not actively violating them (e.g. by not arbitrarily evicting slum dwellers); second, to protect such rights by preventing their infringement by third parties (e.g. by regulating the conduct of exploitative landlords); and third, to fulfil such rights to the extent that resources permit (e.g. through the provision of public or subsidised housing). 
The obligation imposed upon state parties by the ICESCR is that they should take steps towards the full realisation of social, economic and cultural rights, but enforceable duties do not necessarily arise directly or immediately. The result, critics complain, is a yawning gap between promise and reality (e.g. Pogge, 2002). The realisation of all human rights requires time and resources. But the scale and urgency of the task of addressing world poverty starkly attest to the failure of the international community universally to implement an inalienable right to a standard of living adequate for health and well-being (as provided by Article 25 of the UDHR).

Nonetheless, in 2004 the Office of the High Commissioner for Human Rights issued Draft Guidelines for a Human Rights Approach to Poverty Reduction Strategies (OHCHR, 2002). It is encouraging that such a document should be published at all, and yet the Draft Guidelines amount in tone and substance to a sister document to the Millennium Development Goals and the recent Human Development Reports. The underlying premise appears to be that poverty is the antonym of development; poverty is construed as much as a consequence of economic failure as a violation of social rights. The Draft Guidelines explicitly restate the principle of progressive realisation and seek to establish a set of indicators and benchmarks to ensure that economic development is matched in time by social development. The emphasis is on safety nets, good governance and performance monitoring; upon the interdependence of rights and responsibilities, such that for example the right to food should be linked to the right to work; upon the accountability of state parties as well as global actors. The document defines a process for the setting of targets in relation to rights to food, health, education, work, housing, etc., but, significantly, mention of a right to social security (provided by Article 22 of the UDHR) is omitted. If poverty is a violation of rights, the potential of a human rights approach is that it can politicise that gap between the promise offered by international human rights instruments and the reality of world poverty (e.g. Lister, 2004). However, the effect of the Draft Guidelines as presently written is to depoliticise poverty and to collude with a technocratic and essentially managerial approach to development. In practice, it would seem, the Draft Guidelines establish social standards, not welfare rights.

\section{The marginalisation of welfare rights}

Within the welfare states of the developed world, rights to welfare provision have tended to be conditional in nature and systemically subordinate to the specific legal and political context within which they are framed (Dean, 2002). And in the global context, welfare rights have always been marginal. This was reflected in the way the implementation and reporting mechanisms provided by the ICESCR were much weaker than those provided by the equivalent International Covenant on Civil and Political Rights. The Economic and Social Council created by the ICESCR eventually - in1985 - appointed the Committee on Economic Social and Cultural Rights. The Committee receives quinquennial reports from state parties, but its jurisdiction is restricted to the making of 'general comments'. Since 1992 the Committee has invited submissions from non-governmental organisations NGOs, but while international NGOs have been active in monitoring civil and political rights, they have shown less interest in rights to welfare provision (e.g. Hunt, 1996). What is more, new social movements of the global south and their academic allies - the postdevelopment theorists - tend to be hostile to the role of the state as a guarantor of welfare, or else they seek to transcend what they dismiss as the mere 'politics of demand' in favour 
of more authentic forms of political participation (Escobar, 1995; Waterman, 2001). That welfare rights should remain at the margins of the human rights agenda at the beginning of the twenty-first century - despite burgeoning concerns about global poverty - would seem to be attributable to two countervailing, but mutually contradictory, hegemonic preoccupations: one with responsibility; the other with identity.

To observe that rights are related to responsibilities is trite, but true. The relationship between rights and responsibilities is deeply contested. To an extent, however, a precipitating factor had been the 'crisis' that befell the capitalist welfare states from the 1970s onwards (e.g. Mishra, 1984; Pierson, 1998). Associated with the shift in the capitalist world from industrialism to post-industrialism and from Keynesian to monetarist economic orthodoxy had been the ascendancy of a new ideological consensus. During what has been characterised as the 'golden age' of the welfare state (Esping-Andersen, 1996) there had been a broad, if fragile, consensus between those who accepted collective responsibility for human welfare (social democrats and social liberals) and those who accepted mutual obligation and social protectionism (social conservatives and republican traditionalists). The alternative consensus, promoted initially by the so called New Right, was one that combined, on the one hand, neo-conservative support from a strong state and obedience to traditional moral values with, on the other, neo-liberal support for freemarkets and individual responsibility (Gamble, 1988; Roche, 1992). The rights of social citizenship were brought into question by neo-conservatives because they undermined the responsibilities of citizens to sustain themselves through paid employment and to sustain each other within families (Murray, 1984). They were brought into question by neo-liberals because they undermined the ethical freedoms and correlative civic duties of the individual property-owning subject (Nozik, 1974).

The inherent tensions within the New Right are more fluidly accommodated in the 'Third Way' compromise espoused first by Bill Clinton and then by Tony Blair (Jordan, 1998), but whose influence may been seen not only across Europe (Bonoli and Powell, 2002), but also in a wider global context (Deacon, 2003). Central, nonetheless, to the Third Way project is the mantra 'no rights without responsibilities' (Giddens, 1998: 65). This entails both 'new paternalist' (Mead, 1997; Standing, 2002) and 'advanced liberal' (Rose, 1999) elements. New paternalism is characterised by the creeping conditionality that attaches to the administration of welfare rights not only in the developed world (Dwyer, 2004), but also in some parts of the developing world (e.g. Cimadamore et al. 2005). Provision of social benefits for the poor is made conditional upon their willingness to seek employment, undertake training, attend health clinics, and/or send their children to school. Advanced liberalism is a response to the imagined consequences of capitalist globalisation, the crisis of trust in institutions and a transition to a 'risk society' (Beck, 1992; Giddens, 1994). The provision of human services must necessarily embrace a consumerist rather than a public service ethic (Le Grand, 2003). The primary role of welfare states and of social policy in a global context will no longer be to distribute resources or provide directly for people's needs, but to enable people individually to manage risks. The administration of welfare rights, it is supposed, must give way to self-provisioning, prudentialism and an individualistic ethic of self-responsibility.

A very different challenge to welfare rights dates from what has loosely been called the 'cultural turn' in progressive political thinking (e.g. Clarke, 1999), a turn that more or less coincided with the crisis of the welfare state. The concept of welfare rights and social citizenship that originally informed Social Policy was premised on the idea that 
such rights represented the just outcome of a class-based politics that had been concerned to secure some measure of redistribution within systemically unequal capitalist societies. Such assumptions have been called into question by intellectual movements that favour new forms of politics, including a politics of discourse, a politics of identity and a politics of recognition. The cultural turn in the social sciences entailed the burgeoning of a variety of critical theoretical traditions, drawing on theories of ideology and language, symbolic interactionism, social constructionism and post-structuralism, all of which were fundamentally concerned with the practices by which social meanings are generated. While this unleashed extraordinary new insights into social relations of power, one effect was to marginalise the analysis not just of class-based inequalities (Meiskins Wood, 1995), but of social justice and welfare rights as well. Closely allied to this process was the emergence of new social movements - including second wave feminism, the antiracist and disability awareness movements - which drew attention to social divisions other than class and opened up questions about the way in which individual identities are constructed through social differences (Taylor, 1998). By celebrating the sources of their identity, people may demand a different kind of rights: rights not to redistribution, but to participation, empowerment and to recognition (Honneth, 1995; Fraser and Honneth, 2003).

Such insights have had a major impact upon Social Policy, but our understanding of welfare rights has tended to trail behind.

\section{Rediscovering welfare rights}

T.H. Marshall's liberal conception of social citizenship has been criticised because he was inclined to envisage it, abstractly, in terms of an accommodation between competing principles (the principles of the free market versus those of the administrative state) rather than, more concretely, as a political compromise between competing classes (Bottomore, 1992). Welfare rights were seen as having been discovered and handed down from above as a solution to capitalism's tendency to disequilibrium rather than having been struggled for and seized from below by organised labour or through the demands of the poor. Bryan Turner (1990) similarly draws a distinction between 'descending' and 'ascending' views of citizenship and he extends this to a discussion of human rights, arguing that such rights do not merely serve to bolster the autonomy of the human individual, but that 'it is from a collectively held recognition of individual frailty that rights as a system of mutual protection gain their emotive force' (1993: 507; and see Turner, 2006).

What is entailed in these different notions of both citizenship and human rights are two different perceptions or understandings of human dependency (Dean, 2004: chs. 1 and 10). The contractarian perception is averse to dependency and celebrates independence: it seeks to enable people to engage with one another as freely contracting parties. The solidaristic perception acknowledges dependency and celebrates human interdependence: it seeks to enable people to engage with one another in mutually protective solidarity. Contractarian and solidaristic perceptions exist in tension with each other. And each in turn may be inflected towards quite different normative interpretations (ranging from the authoritarian to the egalitarian). By and large, however, it is a spectrum of essentially contractarian perceptions that has achieved ascendancy. ${ }^{2}$

Mid-twentieth century social liberalism had been willing to concede rights to welfare as a means to equality of status and opportunity. The 'advanced liberalism' of the new 
millennium is rather more insistent that rights should not precede the responsibilities of the citizen. Whereas the language of welfare rights was once capable of accommodating either a contractarian or a solidaristic interpretation, the scope for such ambiguity may have been narrowed. Recent research on popular discourse in the UK (see Dean, 2004) would suggest that although a somewhat reluctant awareness of human interdependency and qualified support for welfare rights continue to survive, the ascendancy of an ideological discourse premised upon an individualist ethic of responsibility is having a corrosive affect on people's ability to interpret and support rights to welfare provision as a corollary to, or expression of, their own interdependency.

While several of the new social movements that emerged during the second half of the twentieth century were intent upon celebrating difference and identity, their emphasis on individual identity was on occasions at the expense of solidaristic interpretations of rights. For example, elements of the women's movement have been criticised for middleclass ethnocentricity (Davis, 1981) and/or for pursuing essentially masculine notions of independence (e.g. Pateman, 1989); the disabled people's movement for marginalising the need that all human beings have for care (e.g. Shakespeare, 2000). It would be a mistake, however, to suppose that a concern with the issue of human identity must necessarily lead to an individualistic conception of rights. Taylor (1998) has drawn a distinction between two aspects of identity: 'categorical' and 'ontological'. Our individual identities are constructed through a multiplicity of overlapping categorical identities relating to gender, age, sexuality, ethnicity, religion, abilities, etc. for which we may demand a right to recognition and respect. Our ontological identity, on the other hand, is what defines us as unique human beings in terms of the coherence and unity of the 'self'. Sustaining categorical identities may entail contractarian claims to equal treatment by the individual members of a variety of social groups. Sustaining ontological identity, however, entails solidaristic claims to social protection by or on behalf of unique individuals. Human rights instruments characteristically assert the inherent 'dignity' of all members of the human family. But, as ever, this may be interpreted in contractarian terms as a claim to the equal integrity and autonomy amidst a family of atomistic and self-seeking individuals, or in solidaristic terms as a claim to inclusion and security or 'asylum' (in the original meaning of that word) amidst social diversity. It is this latter interpretation that is under pressure. The welfare rights tradition could be called upon to interpret a right to social security under capitalism as a right to asylum from the risks of an exploitative labour market and/or the risks of poverty in old age; the right to housing as a right to asylum from the risks of homelessness; the right to social care as a right to asylum from the risks of impairment and isolation associated with disability. Insofar as human dignity does require personal autonomy (cf. Doyal and Gough, 1991), this amounts to more than self-sufficiency (Williams, 1999). Dignity comes through social inclusion. Welfare rights entail the right be included with dignity in social relations of interdependency.

Though it is not framed as such, one way of reinvigorating the welfare rights tradition would be through what Nancy Fraser (1989) in her earlier work described as a 'politics of needs interpretation'. It is perhaps through a politics of needs interpretation that specific human needs may be translated into claims and asserted as rights, albeit in a manner that might combine struggles over the redistribution of resources with identity-based struggles for recognition (see Fraser and Honneth, 2003). It may be implied (see Fraser, 1997) that a politics of needs interpretation would require several pre-conditions. It would require, amongst other things, parity of participation and an end to systemic social inequalities; 
effective dialogue between diverse social groups; that 'publicity' - in its literal sense be accorded to the 'private' needs of women and oppressed minorities. This is a vision that ushers in the possibility of welfare rights that are demanded and negotiated from the bottom up; that challenges not only the compromising conditionality of social rights in the developed capitalist world, but also the inhibited and incremental nature of rightsbased approaches to poverty reduction for the global south; and that suggests ways of connecting quotidian understandings of human rights with global social policy. It is not a simple idea, but an attractive one, since it re-establishes welfare rights as unconditional demands in the face of social injustice, both global and local. It is through the language of welfare rights and the processes by which they are negotiated that people may lay claim to the satisfaction of their own needs, while also recognising the claims of distant strangers. What is more, there are signs that the case for such a paradigm shift is more than a scholarly preoccupation. For example, though rarely invoking the language of rights, a draft Social Policy Guidance Note published by the UN's Department of Economic and Social Affairs ventures at one point to assert that 'all the population groups of a country have a right to a decent life (food, clothing, education, health services, employment standards, social security, accessible housing, etc.)' (Ortiz, 2006: 12 [emphasis added]).

\section{Conclusion}

The broad concept of welfare rights that had been developed within Social Policy is under threat as the basis of the capitalist welfare state has come into question. At the same time, it is not a concept that has entered to any significant extent into the prevailing human rights debate. That debate has struggled to give substance to ideas of economic, social and cultural rights, but has never ventured to forge a notion of welfare rights that might have purchase and meaning as much in the global south as in the developed capitalist world. Recent attempts to define a human rights approach to global poverty reduction would seem to embody a managerial rather than an emancipatory ethos.

Fraser's notion of a 'politics of needs interpretation' offers one way of expanding and relocating Social Policy's concept of welfare rights. It suggests a basis on which to engage with the global human rights agenda. Conor Gearty (2006: 43) has recently argued that it is compassion - the 'active concern for others' - that can or should be signified by the term 'human rights': it is the term we use 'when we are trying to describe decency in our post-philosophical world' (ibid: 57). This is not necessarily to concur that human rights provide us with 'values for a godless age' (Klug, 2000), because ultimately, I would contend, human rights are social constructions, not eternal verities. As Ignatieff has put it

rights are not the universal credo of a global society, not a secular religion, but something much more limited and yet just as valuable: the shared vocabulary from which our arguments can begin, and the bare human minimum from which different areas of flourishing can take root. (2001: 95)

The language of human rights undoubtedly represents a discursive resource upon which Social Policy can strategically draw. The challenge is how concretely to re-establish claims to welfare rights within public debate? 


\section{Acknowledgements}

Earlier versions of this paper were presented under the title 'From poverty reduction to welfare rights' at a conference, Crossing the Boundaries: The place of human rights in contemporary scholarship, organised by the Centre for the Study of Human Rights at the London School of Economics and Political Science, UK on 24 March 2006; under the title 'Reconceptualising welfare rights' at a conference, Globalisation and the Political Theory of the Welfare State and Citizenship, organised by the Network of Political Theory in Denmark, at Aalborg University, Denmark on 4-5 May 2006; and under the title 'The significance of the human rights agenda for the future of social policy: imminent threat or strategic opportunity' at a Social Policy Research Centre Seminar, University of New South Wales, Sydney, Australia, 20 July 2006. The author is grateful to Natalie Samarasinghe and Pinar Uyan for helpful comments on earlier versions and for suggestions made by two anonymous referees.

\section{Notes}

1 The convention I adopt in this article is to use a capital ' $\mathrm{S}$ ' and ' $\mathrm{P}$ ' when referring to Social Policy as an academic subject and a lower-case ' $s$ ' and ' $\mathrm{p}$ ' when referring to social policy as substantive intervention for the promotion of human welfare.

2 There are, albeit indirectly, potential parallels between this author's argument (the initial seeds of which were contained in Dean 1999) and the account of human rights rendered by Woodiwiss (2005).

\section{References}

Beck, U. (1992), Risk Society: Towards a New Modernity, London: Sage.

Bonoli, J. and Powell, M. (2002), 'Third Ways in Europe?', Social Policy and Society, 1, 1 pp. $59-66$.

Bordieu, P. (1997), 'The forms of capital', in A. Halsey, H. Lauder, P. Brown and A. Wells (eds), Education, Culture, Economy, Society, Oxford: Oxford University Press.

Bottomore, T. (1992), 'Citizenship and social class forty years on', in T. Marshall and T. Bottomore, Citizenship and Social Class, London: Pluto.

Braathen, E. (2005), 'Social funds in Africa: a technocratic-clientalistic response to poverty', in Cimadamore et al. (eds), The Poverty of the State: Reconsidering the Role of the State in the Struggle Against Global Poverty, Buenos Aires: CLACSO Books.

Cimadamore, A., Dean, H. and Siqueira, J. (eds) (2005), The Poverty of the State: Reconsidering the Role of the Syate in the Struggle Against Global Poverty, Buenos Aires: CLACSO Books.

Clarke, P. Barry (1996), Deep Citizenship, London: Pluto.

Clarke, J. (1999), 'Coming to terms with culture', in H. Dean and R. Woods (eds), Social Policy Review 11, Luton: Social Policy Association.

Clarke, J. (2004), 'Dissolving the public realm? The logics and limits of neo-liberalism', Journal of Social Policy, 33, 1 pp. 27-48.

Clarke, J. and Newman, J. (1997), The Managerial State, London: Sage Publications.

Cranston, M. (1973), What are Human Rights?, London: Bodley Head.

Davis, A. (1981), Women, Race and Class, London: The Women's Press.

Deacon, B. with Hulse, M. and Stubbs, P. (1997), Global Social Policy, London: Sage Publications.

Deacon, B. (2003), 'Global social governance reform', Global Social Policy, 3, 1 pp. 6-17.

Dean, H. with Melrose, M. (1999), Poverty, Riches and Social Citizenship, Basingstoke: Macmillan.

Dean, H. (2002), Welfare Rights and Social Policy, Harlow: Prentice Hall.

Dean, H. (ed.) (2004), The Ethics of Welfare: Human Rights, Dependency and Responsibility, Bristol: The Policy Press.

Doyal, L. and Gough, I. (1991), A Theory of Human Need, Basingstoke: Macmillan. 
Dwyer, P. (2004), 'Creeping conditionality in the UK', Canadian Journal of Sociology, 25, 2 pp. 261-283.

Eide, A. (2001), 'Economic, social and cultural rights as human rights', in A. Eide, C. Krause and A. Rosas (eds), Economic Social and Cultural Rights: A Textbook, 2nd edition, Dordrecht: Martinus Nijhoff.

Escobar, A. (1995), 'Imagining a post-development era', in J. Crush (ed.), The Power of Development, London: Routledge.

Esping-Andersen, G. (1990), The Three Worlds of Welfare Capitalism, Cambridge: Polity.

Esping-Andersen, G. (ed.), (1996), Welfare States in Transition, London: Sage.

Fraser, N. (1989), Unruly Practices: Power, Discourse and Gender in Contemporary Social Theory, Cambridge: Polity.

Fraser, N. (1997), Justice Interruptus: Critical Reflections on the 'Postsocialist' Condition, London: Routledge.Fraser and Honneth 2003.

Fraser, N. and Honneth, A. (2003), Redistribution or Recognition? A Political-Philosophical Exchange, London: Verso.

Gamble, A. (1988), The Free Economy and the Strong State, Basingstoke: Macmillan.

Gearty, C. (2006), Can Human Rights Survive? The Hamlyn Lectures 2005, Cambridge: Cambridge University Press.

Giddens, A. (1994), Beyond Left and Right, Cambridge: Polity.

Giddens, A. (1998), The Third Way, Cambridge: Polity.

Gough, I. and Wood, G. with Barrientos, A., Bevan, P., Davis, P. and Room, G. (2004), Insecurity and Welfare Regimes in Asia, Africa and Latin America: Social Policy in Development Contexts, Cambridge: Cambridge University Press.

Honneth, A. (1995), The Struggle for Recognition: The Moral Grammar of Social Conflicts, Cambridge: Polity.

Hunt, P. (1996), Reclaiming Social Rights, Aldershot: Ashgate.

Ignatieff, M. (2001), Human Rights as Politics and Idolatory, Princeton, NJ: Princeton University Press.

Jordan, B. (1998), The New Politics of Welfare, London: Sage.

Klug, F. (2000), Values for a Godless Age: The Story of the United Kingdom's New Bill of Rights, Harmondsworth: Penguin.

Kymlicka, W. (1995), Multicultural Citizenship: A Liberal Theory of Minority Rights, Oxford: Clarendon Press.

Le Grand, J. (2003), Motivation, Agency and Public Policy: Of knights, Knaves, Pawns and Queens, Oxford: Oxford University Press.

Lister, R. (2004), Poverty, Cambridge: Polity.

Marshall, T.H. (1950), 'Citizenship and social class', in T. Marshall and T. Bottomore (1992), Citizenship and Social Class, London: Pluto.

McLachlan, H. (2005), Social Justice, Human Rights and Public Policy, Glasgow: Humming Earth.

Mead, L. (ed.) (1997), The New Paternalism: Supervisory Approaches to Poverty, Washington, DC: The Brookings Institution.

Meiskins-Wood, E. (1995), Democracy against Capitalism, Cambridge: Cambridge University Press.

Mishra, R. (1984), The Welfare State in Crisis, Hemel Hempstead: Harvester Wheatsheaf.

Mishra, R. (1999), Globalisation and the Welfare State, Aldershot: Edward Elgar.

Murray, C. (1984), Losing Ground: American Social Policy, 1950-1980, New York: Basic Books.

Nozick, R. (1974), Anarchy, State and Utopia, Oxford: Blackwell.

OHCHR (Office of the High Commissioner for Human Rights) (2002), Draft Guidelines for a Human Rights Approach to Poverty Reduction, Geneva: UN.

Ortiz, I. (2006), Social Policy Guidance Note (draft), New York: UN Department of Economic and Social Affairs.

Pateman, C. (1989), The Disorder of Women, Cambridge: Polity.

Perez-Bustillo, C. (2001), 'The right to have rights: poverty, ethnicity, multiculturalism and state power', in F. Wilson, N. Kanji and E. Braathen (eds), Poverty Reduction: What Role for the State in Today's Globalised Economy?, London: CROP/Zed Books. 
Pierson, C. (1998), Beyond the Welfare State, Cambridge: Polity.

Pogge, T. (2002), World Poverty and Human Rights, Cambridge: Polity.

Putnam, R. (2000), Bowling Alone: The Collapse and Revival of American Community, New York: Simon and Schuster.

Roche, M. (1992), Re-thinking Citizenship, Cambridge: Polity.

Rosas, A. (2001), 'The right to development', in A. Eide, C. Krause and A. Rosas (eds), Economic Social and Cultural Rights: A textbook, 2nd edition, Dordrecht: Martinus Nijhoff.

Rose, N. (1999), Powers of Freedom: Reframing Political Thought, Cambridge: Cambridge University Press.

Sen, A. (1999), Development as Freedom, Oxford: Oxford University Press.

Shakespeare, T. (2000), 'The social relations of care', in G. Lewis, S. Gewirtz and J. Clarke (eds), Rethinking Social Policy, London: Sage.

Shue, H. (1980), Basic Rights: Subsistence, Affluence and US Foreign Policy, Princeton, NJ: Princeton University Press.

Standing, G. (2002), Beyond the New Paternalism: Basic Security as Equality, London: Verso.

Taylor, D. (1998), 'Social identity and social policy: engagements with postmodern theory', Journal of Social Policy, $27,3$.

Turner, B. (1990), 'Outline of a theory of citizenship', Sociology, 24. 2 pp. 189-217.

Turner, B. (1993), 'Outline of a theory of human rights', Sociology, 27, 3 pp. 489-512.

Turner, B. (2006), Vulnerability and Human Rights, Pennsylvania: Pennsyvania State University.

UN General Assembly (1993), Vienna Declaration and Programme of Action, New York: UN.

United Nations Development Programme (UNDP) (2000), Human Development Report 2000, Oxford: Oxford University Press.

UNDP (United Nations Development Programme) (2003), Human Development Report 2003 Millennium Development Goals: A Compact Among Nations to End Human Poverty, New York: Oxford University Press.

Waterman, P. (2001), Globalisation, Social Movements and the New Internationalisms, London: Mansell.

Williams, F. (1999), 'Good-enough principles of welfare', Journal of Social Policy, 28, 4 pp. 667-687.

Williamson, J. (1990), 'What Washington means by policy reform', in J. Williamson (ed.), Latin American Adjustment: How Much Has Happened? (Washington: Institute for International Economics).

Woodiwiss, A. (2005), Human Rights, London: Routledge.

Wronka, J. (1992), Human Rights and Social Policy in the 21st Century, Lanham, MA: University Press of America. 